\title{
PENGEMBANGAN PEMBELAJARAN EKOLOGI HEWAN BERBASIS PROYEK DAN POTENSI LOKAL KAWASAN DANAU TOBA
}

\author{
Retnita Ernayani Lubis*, Mimien Henie Irawaty, Ibrohim, Sri Endah Indrawati \\ Program Studi Pendidikan Biologi Universitas Negeri Malang, Jl. Jl. Semarang No.5, Sumbersari, Kec. Lowokwaru, \\ Kota Malang, Jawa Timur 65145 \\ *Korespondensi Author: retnitalubis@gmail.com
}

\section{INFO ARTIKEL}

Histori Artikel

Received 2 Mei 2019

Revised 2 Juli 2019

Accepted 20 Juli 2019

Published 13 Agustus 2019

\section{Keywords:}

Learning Animal Ecology, Project Based Learning, Local Potential.

\begin{abstract}
The study aimed to develop a valid and practical project-based animal ecology learning plan and local potential of Lake Toba. Development research uses the Thiagarajan 4D model. The results showed that in the define phase mapping of the basic competencies of Animal Ecology was produced and the material of the local potential of the Lake Toba Region and learning objectives. The design phase shows the format of the learning device developed. The develope stage shows the results of validation by the validator stating that project-based Animal Ecology learning tools and local potential are declared valid with a mean of RPS 93; Research Instrument 88.4; Student Worksheet 88.6; SAP 90.5; and the results of the student response questionnaire on positive learning devices. Project-based Animal Ecology learning devices and the generated local potential of Lake Toba have met valid and practical criteria.
\end{abstract}

Copyright (C) 2019 Universitas Negeri Medan. Artikel Open Access dibawah lisensi CCBY-4.0 (https://creativecommons.org/licenses/by/4.0)

\section{How to Cite:}

Lubis, R.E., Irawaty, M.H., Ibrohim \& Indrawati, S.E. (2019). Pengembangan Pembelajaran Ekologi Hewan Berbasis Proyek dan Potensi Lokal Kawasan Danau Toba. Jurnal Pelita Pendidikan, 7(2), 071-079.

\section{PENDAHULUAN}

Dunia Pendidikan pada Abad 21 ditantang untuk mampu menciptakan tata pendidikan yang dapat ikut menghasilkan sumber daya pemikir yang mampu ikut membangun tatanan sosial dan ekonomi sadar-pengetahuan sebagaimana layaknya warga dunia di Abad-21 (Mukminan, 2014). Pembelajaran Abad 21 memiliki peluang, tantangan, dan masalah yang sangat berbeda dengan masa-masa sebelumnya. Agar Iulusan perguruan tinggi mampu mengambil peran dalam abad 21 maka diperlukan penguasaan keterampilan abad 21 yang dapat dicapai melalui proses pendidikan, karena pendidikan memiliki peranan dalam mempersiapkan peserta didik untuk menjadi warga global dan siap untuk tantangan yang terkait dengan masyarakat yang didominasi teknologi (Chu, 2018).

Burkhardt (2003) dan Chalkiadaki (2018) menyatakan keterampilan Abad 21 harus dipertimbangkan secara ketat didalam konteks standar akademik, yaitu harus secara autentik dan 
mengasah kemampuan kerja siswa. Muatan materi, metode pembelajaran, hingga kecakapan yang menjadi standar pembelajaran Abad ke-21 mendorong setiap insan pendidikan untuk mampu menyesuaikan diri dengan kebutuhan saat ini. Oleh karena itu dunia pendidikan harus membenahi kurikulum, manajemen pendidikan, tenaga pendidikan, strategi dan metode pendidikan, serta sistem evaluasi yang sesuai dengan abad 21 (Wibowo, 2014).

Sistem Pendidikan seharusnya menjadi pendukung dan administrator bagi guru untuk dapat memperkuat pengajaran, kepemimpinan dan kapasitas manajemen serta menciptakan lingkungan belajar yang kondusif (Vockley, 2008). Selain itu, tuntutan pembelajaran Abad 21 melingkupi; beberapa keterampilan dalam penilaian akademik, yaitu digital literasi, kemampuan berpikir, kemampuan komunikasi yang efektif dan kemampuan produktivitas tinggi (Burkhardt, 2003; Vockley, 2008), kemampuan penemuan (kreatif dan inovatif) Informasi, media dan kemampuan teknologi; kurikulum; assessment; dan pembelajaran lingkungan (Wijaya, 2016; Haryono, 2017; Khaerudin, 2017).

Bagi guru, tidak saja harus mahir dengan keterampilan akademiknya tetapi juga harus terampil hidup bersosialisasi dengan teknologi komunikasi yang tersedia disekitarnya, sehingga guru pada abad 21 harus dipersiapkan untuk memberikan kesempatan belajar yang didukung teknologi bagi siswa dan harus tahu bagaimana teknologi dapat mendukung siswa belajar (Prasetyo, 2017). Dengan kata lain, perguruan tinggi yang mencetak calon guru harus dapat mendukung dan menjadi administrator untuk tercapainya kompetensi di Abad 21.

Pemberian pembelajaran mengguanakan model Pembelajaran Berbasis Proyek dapat menjadi solusi untuk pembelajaran pada mata kuliah Ekologi Hewan untuk meningkat suasana aktif dan menyenangkan di kelas. Pembelajaran Berbasis Proyek dapat menstimulasi motivasi, proses, dan meningkatkan prestasi belajar siswa dengan menggunakan masalah-masalah yang berkaitan dengan matakuliah tertentu pada situasi nyata (Fikri, 2014). Pembelajaran berbasis proyek memungkinkan siswa memperluas wawasan pengetahuan dan keterampilan sehingga pembelajaran menjadi lebih bermakna dan kegiatan pembelajaran menjadi lebih menarik. Hal itu terjadi karena pengetahuan bermanfaat bagi dirinya, untuk mengapresiasikan lingkungan, lebih memahami dan memecahkan masalah yang dihadapi siswa dalam kehidupan sehari-hari (Amini, 2015). Bagheri (2013) menyatakan dengan pemberian Pembelajaran Berbasis Proyek mahasiswa dapat melakukan beragam aktivitas melalui kemampuan mereka sendiri yang ditingkatkan dengan melihat kemampuan memanagemen waktu, oritentasi hasil, mengendalikan pembelajaran sendiri, rasa tanggungjawab terhadap pembelajaran orang lain, penilaian diri, kemampuan mengambil keputusan berdasarkan informasi dan lainnya.

Model pembelajaran berbasis proyek mendefinisikan belajar sebagai sebuah proses, di mana pengetahuan dikonstruksi melalui transformasi pengalaman. Seseorang belajar jauh lebih baik melalui keterlibatannya secara aktif dalam proses belajar, yakni berpikir tentang apa yang dipelajari dan kemudian menerapkan apa yang telah dipelajari dalam situasi nyata. Model ini lebih fokus pada pengkonstruksian pengetahuan mahasiswa, di mana mahasiswa diharapkan dapat menemukan informasi penting dalam mengkostruksi pengetahuan sendiri (Siwa, 2013).

Pembelajaran berbasis potensi lokal merupakan salah satu bentuk pembelajaran yang kontekstual. Pembelajaran kontekstual merupakan konsep belajar dimana dosen dapat menghadirkan dunia nyata ke dalam kelas dan mendorong mahasiswa membuat hubungan antara pengetahuan yang dimilikinya dengan penerapannya pada kehidupan sehari-hari. Pembelajaran kontekstual menyajikan suatu konsep yang mengaitkan materi pelajaran yang dipelajari mahasiswa dengan konteks materi terserbut digunakan, serta hubungan bagaimana seseorang belajar atau cara mahasiswa belajar (Hosnan, 2014: 267-268). Menurut Preston (2015) manfaat pendidikan berbasis lokal meliputi; penguatan hubungan antara mahasiswa/sekolah dan masyarakat, mengurangi keterasingan mahasiswa melalui peningkatan relevansi dan keaslian pengalaman belajar, memberikan kesempatan bagi mahasiswa untuk berpartisipasi aktif dalam proses demokrasi termasuk 
pemecahan masalah dan pengambilan keputusan, meningkatkan apresiasi mahasiswa pada lingkungan lokal mereka, dan membina melek ekologi.

Hasil analisis di atas membuktikan perlu adanya perangkat khusus pembelajaran berbasis proyek berpotensi lokal yang membahas kajian Ekologi Hewan di Kawasan Danau Toba. Sehingga perlu dilakukan pengembangan pembelajaran berbasis proyek berpotensi lokal Kawasan Danau Toba.

\section{METODE PENELITIAN}

Penelitian ini merupakan penelitian pengembangan. Pengembangan perangkat pembelajaran Ekologi Hewan berbasis Project Based Learning berpotensi lokal Kawasan Danau toba dilakukan menggunakan penelitian pengembangan yang dikembangkan oleh Thiagarajan, Semmel and Semmel (1974) yang dikenal dengan Model 4-D. Pengembangan perangkat tersebut meliputi empat tahap, yaitu: Define (Pendefinisian), Design (Perancangan), Develope (Pengembangan) dan Disseminate (Penyebaran).

\section{HASIL DAN PEMBAHASAN}

\section{Hasil Penelitian Tahap Define}

1. Front-end Analysis

Hasil analisis menyatakan pengunaan model-model pembelajaran dan potensi lokal masih kurang diterapkan dalam perencanaan dan penyapaian pembelajaran. Penggunaan modelmodel pembelajaran dan potensi lokal tidak langsung terkonsep secara tertulis sebagai rencana pembelajaran melainkan secara tersisipkan ketika memberikan contoh pada materi-materi tetentu pada matakuliah Ekologi Hewan. Berdasarkan hasil analisis tersebut, kemudian dikembangkan perangkat pembelajaran berbasis proyek dan potensi lokal Kawasan Danau Toba serta buku ajar berbasis potensi lokal.

2. Learner Analysis

Karakteristik mahasiswa adalah berhubungan dengan kesiapan mahasiswa untuk mengikuti segala kegiatan matakuliah berdasarkan latar belakang pengetahuan, pengalaman belajar, sikap dan kompetensi matakuliah Ekologi Hewan. Latar belakang mahasiswa sebagai subyek penelitian kurang memiliki pengetahuan dasar mengenai Ekologi Hewan, akan tetapi sebagian besar mahasiswa Pendidikan Biologi sudah mengenal Danau Toba karena berasal dari daerah tersebut. Pengalaman belajar mahasiswa selama mengikuti pembelajaran, yaitu kegiatan pembelajaran di kelas, kegiatan praktikum dan kegiatan lapangan. Sikap mahasiswa pendidikan biologi terhadap matakuliah Ekologi Hewan baik.

3. Task Analysis

Thiagarajan (1974) menyatakan task analysis dilakukan dengan mengidentifikasi kegiatan-kegiatan yang terjadi selama proses pembelajaran berlangsung, melitputi kegiatan dosen-mahasiswa, tugas-tugas mahasiswa dan proses evaluasi pembelajaran Ekologi Hewan. Kegiatan dosen-mahasiswa di kelas meliputi kegiatan belajar-mengajar dengan metode konvensional ceramah dan diskusi presentasi, tugas-tugas mahasiswa seputar materi untuk dipresentasikan di depan kelas. Tugas-tugas mahasiswa terbagi pada: (1) tugas mandiri yang dikerjakan secara perorangan dengan tagihan berupa laporan atau makalah; (2) tugas kelompok yang dikerjakan secara bersama dalam kelompok untuk mendiskusikan dan mempresentasikan sesuai topik yang ditugaskan dengan tagihan berupa powerpoint dan makalah; (3) menganalisis atau mengulas secara tuntas suatu topic materi perkuliahan secara kelompok atau mandiri; (4) ujian formatif.

Kegiatan praktikum, mahasiswa biasanya dipandu oleh dosen untuk melakasanakan kegiatan dengan dibantu bebrapa asisten di laboratorium, selanjutnya mahasiswa diberi tugas untuk membuat laporan hasil pengamatan. Selain itu, masih ada kegiatan lapangan untuk mengaplikasikan kegiatan Ekologi Hewan secara nyata di lapangan. Tugas-tugas pada matakuliah praktikum Ekologi Hewan, yaitu: (1) tugas mandiri; (2) tugas kelompok; (3) laporan kuliah lapangan; (4) ujian formatif. Hasil identifikasi tersebut tertuang dalam 15 Kompetensi Dasar yang terdapat pada matakuliah Ekologi Hewan yang selanjutnya digunakan dalam pengembangan perangkat pembelajaran berbasis proyek dan potensi lokal Kawasan Danau Toba. Pengembangan perangkat pembelajaran mulai 
dari RPS, SAP, Lembar Kerja, Instrumen Penilaian dan Buku Ajar Ekologi Hewan menggunakan Kompetensi Dasar tersebut dengan menambahkan materi potensi lokal.

\section{Concept Analysis}

Tahap ini, dilakukan analisis kompetensi dasar matakuliah Ekologi Hewan dan materi potensi lokal Kawasan Danau Toba. Hal ini bertujuan untuk mengetahui konsep-konsep Ekologi Hewan dan konsep-konsep materi potensi lokal, sehingga dapat digabungkan dengan konsep Ekologi Hewan. Analisis ini dilakukan dengan cara memetakan kompetensi dasar matakuliah Ekologi Hewan dan materi potensi lokal yang akan digunakan pada matakuliah Ekologi Hewan.

Hasil pemetaan konsep potensi lokal Kawasan Danau Toba sebagai berikut;

\section{a. Potensi Budaya}

Kebudayaan Batak didasari pada Dalihan Natolu yang mana sistem kekerabatan, pola hubungan sehari-hari baik dengan Tuhan, leluhur, keluarga, tetangga dan sesama. Banyak kebudayaan batak, diantaranya seni tari, tenun dan pahatan yang mana memiliki nilai filosofi yang kental. Bagi masyarakat Batak menenun adalah salah satu mata pencaharian dari masa dahulu, hasil dari tenunan disebut dengan ulos. Ulos adalah kain yang digunakan masyarakat batak pada zaman dahulu sebagai selimut. Akan tetapi semakin berkembangnya zaman ulos dianggap sakral karena digunakan untuk upacara-upacara adat seperti upacara perkawinan dan kematian. Dalam upacara-upacara adat selain ulos, tari tortor juga merupakan bagian terpenting. Setiap gerakan dalam tarian tor-tor mengandung makna, tergantung jenis upacara adat yang dilakukan. Rumah Adat Batak memiliki ukiran-ukiran yang mengandung makna, ukiran tersebut dinamakan gorga. Pada rumah adat Batak gorga yang terpahat mengandung makna tertentu sesuai dengan orang yang tinggal di dalam rumah tersebut. Rumah adat Batak biasanya bukan hanya untuk tempat tinggal, akan tetapi sekaligus digunakan sebagai lumbung padi dan tempat hewan ternak.

\section{b. Potensi Alam}

Kawasan Danau Toba merupakan habitat bagi organisme-organisme air dan daratan. Pada awalnya perairan Danau Toba merupakan perairan yang kurang subur (miskin hara) atau disebut juga sebagai Oligotrofik, sehingga hanya sedikit organisme-organisme air yang dapat hidup. Semakin berkembangnya ilmu pengetahuan terutama dibidang perternakan ikan, perairan Danau Toba beralih fungsi sebagai wadah untuk perkembangbiakan ikan secara masal melaui KJA (Kerambah Jaring Apung). Berkembangnya KJA mengakibatkan semakin banyaknya ikan-ikan introduksi di perairan Danau. Masuknya ikan introduksi mengakibatkan tersisihnya ikan endemik Danau Toba, yaitu ikan Batak sehingga populasi ikan Batak di perairan Danau Toba berkurang bahkan terancam punah. Pemberian pakan ikan pada KJA yang tidak sesuai mengakibatkan terjadinya pengendapan sedimen di dasar perairan, sehingga nilai Total Posfor (TP) dan Total Nitrogen (TN) pada perairan danau meningkat. Nilai Total Posfor dan Total Nitrogen merupakan indikator tetapan trofik suatu perairan. Tingginya nilai TP dan TN pada perairan Danau Toba mengakibatkan perubahan sifat perairan danau menjadi mesotrofik. Selain itu, tingginya nilai TP dan TN pada perairan danau, juga mengindikasikan tingginya endapan sedimen di dasar perairan mengakibatkan terjadinya kematian masal ikan-ikan pada KJA tiap tahunnya.

5. Specifying Instrutional Objectives

Tahap ini, hasil concept analysis dan task analysis dirumuskan menjadi capaian pembelajaran matakuliah Ekologi Hewan. Capaian pembelajaran tersebut kemudian menjadi dasar dalam penyusunan rancangan dan evaluasi pembelajaran, dalam hal ini adalah perangkat pembelajaran. Perumusan ini berdasarkan hasil task analysis dan concept analysis. Hasil tahap ini didapatkan tujuan pembelajaran matakuliah Ekologi Hewan.

\section{Hasil Penelitian Tahap Design}

\section{Constructing Criterion-Referenced Tes}

Tes acuan yang dimaksud adalah instrumen penelitian yang digunakan untuk menghasilkan perangkat pembelajaran yang valid dan praktis. Instrumen yang dibuat berupa lembar validasi, lembar observasi, angket respon dan tes hasil belajar. Lembar validasi adalah lembar penilaian yang digunakan untuk menvalidasi perangkat pembelajaran Ekologi Hewan berbasis proyek dan 
potensi lokal Kawasan Danau Toba. Komponen lembar validsi meliputi komponen isi, bentuk penyajian dan kebahasaan.

Lembar observasi keterlaksanaan pembelajaran digunakan untuk kepraktisan produk yang dikembangkan. Lembar observasi diberikan kepada dosen dan tim observer untuk menilai keterlaksanaan penggunaan perangkat pembelajaran di lapangan. Angket respon diberikan kepada dosen dan mahasiswa. Angket respon diberikan kepada dosen untuk menunjukkan respon dosen terhadap perangkat pembelajaran yang telah disusun. Sedangkan angket respon mahasiswa meliputi penilaian mahasiswa terhadap pembelajaran berbasis proyek dan potensi lokal Kawasan Danau Toba. Amgket respon juga digunakan untuk menilai kepraktisan produk yang dihasilkan. Angket respon dinyatakan dengan tanggapan positif dan negatif. Tes hasil belajar merupakan instrumen tes yang digunakan untuk menilai keefektifan pembelajaran berbasis proyek dan potensi lokal Kawasan Danau Toba. Tes yang digunakan adalah tes hasil belajar bentuk esai.

\section{Media Selection}

Pemilihan media dilakukan untuk memilih media yang sesuai dengan isi pembelajaran. Pemilihan media ini dilakukan berdasarkan task analysis dan concept analysis serta fasilitas yang tersedia di kampus dan karakteristik mahasiswa. Hal ini berguna untuk membantu mahasiswa dalam pencapaian Kompetensi Dasar. Pemilihan media dilakukan untuk memberikan solusi atas permasalahan yang ditemukan pada front-end analysis. Media yang akan digunakan berupa media print berupa artikel yang sesuai dengan kegiatan proyek yang akan dikerjakan oleh mahasiswa.

\section{Format Selection}

Tahap ini dimaksudkan untuk merancang format isi, sumber belajar, strategi, pendekatan dan metode pembelajaran yang sesuai dengan potensi lokal. Format perangkat pembelajaran yang disusun berdasarkan kurikulum berbasis KKNI. Format buku yang disusun terdiri bagian pendahuluan berisi pengantar sejarah Danau Toba, bagian isi berisi kajian Ekologi Hewan di Kasawasan Danau Toba. Model pembelajaran yang digunakan dalam pengembangan perangkat pembelajaran adalah Project Based Learning.

\section{Initial Design}

Rancangan perangkat pembelajaran yang disusun berupa RPS, SAP, Lembar Kerja dan Instrumen penilaian. Perangkat pembelajaran yang disusun merupakan perangkat pembelajaran yang diperuntukkan unuk dosen dan mahasisawa, dengan haarapan perangkat pembelajaran tersebut dapat membantu dosen dan mahasiswa untuk dapat melaksanakan pembelajaran Ekologi Hewan berbasis potensi lokal Kawasan Danau Toba.

Proses pengembangan perangkat pembelajaran Ekologi Hewan berbasis proyek dan potensi lokal Kawasan Danau Toba mengacu pada capaian pembelajaran yang disusun program studi Pendidikan Biologi Fakultas Matematika dan IImu Pengetahuan Alam Universitas Negeri Medan. Terdapat 15 capaian pembelajaran matakuliah pada Ekologi Hewan dan sudah mencakup keseluruhan capaian pembelajaran lulusan yang disusun Program Studi. Berdasarkan Perpres No 8 Tahun 2012 capaian pembelajaran meliputi aspek pengetahuan, sikap, keterampilan, kompetensi dan akumulasi pengalaman kerja. Capaian pembelajaran matakuliah tersebut diintegrasikan dengan materi potensi lokal yang sesuai dengan matakuliah Ekologi Hewan. Setelah itu, dirumuskan indikator pembelajaran dan tujuan pembelajaran yang teruang pada RPS dan SAP yang dikembangkan.

\section{a. Penyusunan RPS}

RPS adalah acuan penyusunan kerangka pembelajaran yang terdiri atas capaian pembelajaran, capaian pembelajaran mata kuliah, indikator pencapaian kompetensi, pengalaman belajar mahasiswa dan teknik penilaian (diadaptasi dari BNSP Tahun 2010). Langkahlangkah pengembangan RPS mencakup; (1) menentukan capaian pebelajaran; (2) menentukan capaian pembelajaran matakuliah; (3) menentukan indicator pencapaian kompetensi; (4) pemilihan model pembelajaran; (5) menentukan teknik penilaian; dan (6) menentukan sumber belajar. Capaian pembelajaran matakuliah sudah mencakup materi potensi lokal yang sudah dijabarkan sebelumnya pada tahap define. Model pembelajaran yang 
digunakan dilengkapi dengan sintak pembelajaran sehingga memudahkan untuk melihat bagaimana suatu materi itu diajarkan.

\section{b. Penyusunan SAP}

SAP yang dikembangkan berdasarkan pada model pembelajaran berbasis proyek dan potensi lokal Kawasan Danau Toba. Pemberian materi potensi lokal pada SAP dilakukan dengan menyesuaian materi Ekologi Hewan dan materi potensi lokal. Salah satu cara penyesuaian materi potensi lokalnya dengan melakukan kegiatan lapangan ke Kawasan Danau Toba dan memberikan informasi melalui literatur mengenai kondisi Danau Toba pada mahasiswa pada skenario pembelajan SAP.

c. Penyusunan Lembar Kerja

Lembar Kerja (LK) dirancang berdasarkan sintas model pembelajaran dengan mencakup materi potensi lokal. Lembar kerja digunakan pada kegiatan lapangan sebagai bentuk aplikasi terhadap materi potensi lokal Kawasan Danau Toba. Sehingga menghasilkan LK dengan muatan materi potensi lokal yang relevan dan sesuai dengan tujuan yang ingin dicapai pada setiap pembelajaran. Model pembelajaran yang digunakan adalah pembelajaran berbasis proyek, sehingga LK yang disusun merupakan LK berbasis proyek dan potensi lokal Kawasan Danau Toba.

d. Penyusunan Instrumen Penilaian
Instumen penilaian yang disusun adalah lembar penilaian untuk keterlaksanaan kegiatan pembelajaran. Instrumen penilaian yang disusun adalah lembar observasi pembelajaran, lembar observasi mahasiswa, lembar penilaian hasil produk, lembar penilaian kinerja, lembar penilaian laporan, lembar penilaian presentasi dan lembar penilaian unjuk kerja. Lembar observasi yang disusun ada dua jenis, yaitu lembar observasi pembelajaran yang berfungsi untuk melihat keterlaksanaan kegiatan pembelajaran oleh dosen. Lembar observasi mahasiswa berfungsi untuk melihat keterlaksanaan kegiatan pembelajaran mahasisawa berdasarkan pembelajaran di kelas. Selain dari pada lembar penilaian di atas, instrumen penilaian yang lain berupa tes hasil belajar dan rubrik untuk menilai jawaban soal tes hasil belajar.

\section{Hasil Peneitian Tahap III (Develope)}

\section{Expert Apprasial}

Seluruh produk yang telah dirancang dinilai kelayakannya oleh para ahli. Ahli yang menilai adalah ahli di bidang Ekologi Hewan dan ahli di bidang Pendidikan. ). Para ahli diberikan draf rancangan produk dan lembar validasi yang akan digunakan untuk menilai kelayakan produk yang telah dirancang.

Tabel 1 Analisis Hasil Penilaian Produk

\begin{tabular}{|c|c|c|c|c|c|c|c|}
\hline \multirow[t]{3}{*}{ No } & \multirow[t]{3}{*}{ Produk } & \multicolumn{6}{|c|}{ Rerata Hasil Penilaian Validator } \\
\hline & & \multicolumn{4}{|c|}{ Ahli Ekologi Hewan } & \multirow[t]{2}{*}{$\begin{array}{c}\text { Praktisi } \\
\text { Pendidikan }\end{array}$} & \multirow[t]{2}{*}{ Kategori } \\
\hline & & 1 & Kategori & 2 & Kategori & & \\
\hline 1. & RPS & 92,7 & Valid & 90 & Valid & 96,3 & Valid \\
\hline 2. & $\begin{array}{l}\text { Intrumen } \\
\text { Penilaian }\end{array}$ & 86,3 & Valid & 88,1 & Valid & 90,9 & Valid \\
\hline 3. & Lembar Kerja & 86 & Valid & 90 & Valid & 90 & Valid \\
\hline 4. & SAP & 85,8 & Valid & 88,2 & Valid & 97,6 & Valid \\
\hline
\end{tabular}

Berdasarkan Tabel 1 disimpulkan bahwa semua produk pengembangan dinyatakan memenuhi syarat kevalidan. Assalma (2013) menyatakan hasil validasi lembar kerja siswa dengan pendekatan project based learning dan berwawasan salingtemas menunjukkan hasil yang valid dan hasil tanggapan yang posif dari siswa dan guru, sehingga dapat digunakan dalam pembelajaran.

\section{Developmental Testing}

Tahap ini dilakukan untuk melihat respon mahasiswa terhadap perangkat pembelajaran yang sudah disusun dan divalidasi. Hasil respon mahasiswa pada perangkat pembelajaran dilakukan dengan melakukan pre-eksperimen dengan menggunakan The One Group PretestPosttest Design. Respon mahasiswa tersebut dianalisis melalui angket respon peragkat pembelajaran. Berikut tabel penjelasan hasil 
analisis angket respon mahasiswa terhadap perangkat pembelajaran berbasis proyek dan potensi lokal

Tabel 2 Analisis Angket Respons Mahasiswa

\begin{tabular}{llcccccc}
\hline \multirow{2}{*}{ No } & \multirow{2}{*}{ Perangkat Pembelajaran } & \multicolumn{5}{c}{ Respon Mahasiswa } \\
\cline { 3 - 7 } & & \multicolumn{2}{c}{ Bahasa } & Kesesuaian Konten & Kelayakan \\
\cline { 3 - 7 } & & $\%$ & Kategori & $\%$ & Kategori & $\%$ & Kategori \\
\hline 1. & Lembar Kerja & 79.54 & Positif & 81.67 & Positif & 79.33 & Positif \\
2. & Instrumen Penilaian & 77.78 & Positif & 73 & Positif & 73.67 & Positif \\
\hline
\end{tabular}

Berdasarkan Tabel 2 di atas menyatakan secara keseluruhan mahasiswa memberikan respon positif terhadap perangkat pembelajaran berbasis proyek dan potensi lokal Kawasan Danau Toba. Bagi mahasiswa pembelajaran berbasis proyek memberikan banyak manfaat, terutama mahasiswa lebih mudah memahami topik-topik materi pada pembelajaran Ekologi Hewan. Mengingat matakuliah Ekologi Hewan membutuhkan keterampilan di lapangan, pembelajaran berbasis proyek dan potensi lokal sangat membantu mahasiswa untuk dapat mengasah kemampuan mereka dalam pengambilan sampel dan menganalisis hasil temuan selama di lapangan serta mereka lebih dapat lebih mengenal sumber kekayaan alam pada Kawasan Danau Toba. Hatimah (2006) menyatakan model pengelolaan pembelajaran berbasis potensi lokal di PKBM dapat diimplementasikan secara efektif dan berhasil guna, hal ini didasarkan pada respon positif dari pengelola PKBM, tutor dan warga belajar terhadap implementasi pengelolaan pemebelajaran berbasis potensi lokal.

Pada instrumen penilaian, persentase respon mahasiswa sekitar $73-77 \%$ untuk ketiga kategori respon. Hal ini dikarenakan, mahasiswa masih belum terbiasa menggunakan beberapa instrumen penilaian pada kegiatan pembelajaran baik di kelas maupun di lapangan. Akan tetapi, mahasiswa masih dapat memberikan respon positif pada penggunaan instrumen penilaian tersebut.

Respon yang paling tinggi berada pada penggunaan Lembar Kerja Mahasiswa. Lembar Kerja ini dimaksudkan untuk memudahkan mahasiswa untuk mengikuti kegiatan lapangan dan mereka merancang sendiri kegiatan lapangan tersebut, sehingga mahasiswa merasa diberikan kesempatan untuk dapat mengelola seluruh kegitan mereka selama dilapangan.

Suratsih (2010) menyatakan pemilihan potensi lokal yang sesuai dengan pembelajaran biologi dapat dibuat sumber-sumber belajar dan perangkat pembelajaran untuk pengembangan pembelajaran biologi. Penggunaan potensi lokal pada pembelajaran dapat berlangsung dengan menyediakan fasilitas pembelajaran seperti ketersedian perangkat, sumber belajar dan media pembelajaran. Ketersedian perangkat pembelajaran berbasis potensi lokal akan memudahkan menyampaiakan materi-materi potensi lokal pada pembelajaran, terutama pembelajaran biologi.

Pengembangan perangkat pembelajaran Ekologi Hewan berbasis proyek dan potensi lokal Kawasan Danau Toba dimulai dari pemetaan kompetensi dasar matakuliah dan pemetaan potensi lokal. Pemetaan kompetensi dasar matakuliah dilakukan dengan menganalisis RPS dan SAP maatakuliah Ekologi Hewan, hasil analisis didapatkan 15 kompetensi dasar pada matakuliah Ekologi Hewan. Pemetaan potensi lokal Kawasan Danau Toba dilakukan dengan kajian literasi dan kunjungan langsung untuk mendapatkan kegiatan lapangan yang akan disesuaikan dengan kompetensi dasar matakuliah. Pemetaan potensi lokal menghasilkan materi-materi Ekologi Hewan yang sudah disesuaikan dengan kegiatan pembelajaran matakuliah tersebut. Suratsih (2010) menyatakan untuk menghasilkan produk pengembangan pembelajaran potensi lokal, perlu dilakukan pemetaan potensi lokal disuatu Kawasan dan dihubungkan dengan Kompetensi Dasar pada kurikulum pembelajaran, sehingga dapat diketahui produk pembelajaran potensi lokal yang ingin dikembangkan. Pemilihan materi potensi lokal tersebut dilakukan dengan hati-hati dan cermat serta disesuaikan dengan capaian dan 
tujuan pembelajaran matakuliah sehingga dapat disesuaikan pada matakuliah Ekologi Hewan.

\section{KESIMPULAN}

Perangkat pembelajaran Ekologi Hewan berdasarkan Pembelajaran Berbasis Proyek berpotensi lokal Danau Toba yang dihasilkan sudah memenuhi kriteria valid dan praktis.

\section{DAFTAR PUSTAKA}

Assalma, NE, Enni Suwari Rahayu, Retno Sri Iswari. 2013. Pengembangan Lembar Kerja Siswa dengan Pendekatan Pembelajaran Berbasis Proyek (PBP) dan Berwawasan Salingtemas. Unnes Journal of Biology Education. 2(1). http://journal.unnes.ac.id/sju/index.php/uj eb.

Amini, R. 2015. Pengaruh Penggunaan Project Based Learning dan Motivasi Belajar Terhadap Hasil Belajar Siswa Kelas V SD. Prosiding Seminar Nasional Pendidikan Biologi 21 Maret 2015.

Bagheri, M., Wan Z.W.A., Maria C.A., Shaffe M.D. 2013. Effects of Project-based Learning Strategy on Self-directed Learning Skills of Educational Technology Students. Contemporary Educational Technology, (online), 4(1), 15-92, diakses 20 Januari 2015.

Burkhardt, Gina. 2003. Engauge 21st Century Skills. California: Metiri Group.

Chu, S., Reynolds R., Notari M., Taveres N., Lee C. 2018. 21st Century Skills Development Through Inquiry Based Learning From Theory to Practice. Singapore: Springer science.

Chalkiadaki, A. 2018. A Systematic Literature Review of 21st Century Skills and Competencies in Primary Education. Internasional Journal of Instructions. Vol 11, No 3 p-ISSN: 1694-609X. e-ISSN: 1308-1470. www.e-iji.net. Diakses pada 3 April 2019.

Dyjur, Patti., Lilian Li. 2015. Learning 21st Century Skills by Engaging in An Infographics Assignment. Proceedings of the IDEAS, pp.62-71. University of Calgary.

Fikri, K. 2014. Pengembangan e-Portopolio dalam Project Based Learning pada Matakuliah Animal Physiology pada Program Studi Pendidikan Biologi. Pancaran. Vol 3, No 2: 17-24
Hosnan, M.2014. Pendekatan Saintifik dan Kontekstual dalam Pembelajaran Abad 21: Kunci Sukses Implementasi Kurikulum 2013. Bogor: Ghalia Indonesia.

Khaerudin. 2017. Tren dan Tantangan bagi Teknologi Pendidikan di Abad 21. Ilmu Pendidikan.net, Blog bagi yang peduli dengan Dunia Pendidikan. www.ilmupendidikan.net.

Mukminan. 2014. Tantangan Pendidikan di Abad 21. Makalah seminar Nasional Teknologi Pendidikan: Peningkatan Kualitas Pembelajaran Pendayagunaan Teknologi Pendidikan, Universitas Negeri Surabaya 29 November 2014. Diakses pada 4 Maret 2019.

Prasetyo, Zuhdan Kun. 2017. Pembelajaran dan Kompetensi Pendidik Abad 21. Inovasi Pendidikan Bunga Rampal Kajian Pendidikan Karakter, literasi dan Kompetensi Pendidik dalam Menghadapi Abad 21. Diakses pada 4 Maret 2019.

Preston, L. 2015. The Place of Place-Based Education in the

Australian Primary Geography Curriculum. Geographical Education VOLUME 28, (online), diakses pada 13 Maret 2016.

Rochmad. 2012. Desain Model Pengembangan Perangkat Pembelajaran Matematika. Jurnal Kreano. Vol 3 No 1. ISSN: 2086-2334.

Siwa, I.B., I.W. Muderawan., I.N.Tika. 2013. Pengaruh Pembelajaran Berbasis Proyek Dalam Pembelajaran Kimia Terhadap Keterampilan Proses Sains Ditinjau Dari Gaya Kognitif Siswa. e-Journal Program Pascasarjana Universitas Pendidikan Ganesha Program Studi IPA, 3, (online)

Suratsih. 2010. Pengembangan Modul Pembelajaran Biologi Berbasis Potensi Lokal dalam Kerangka Implementasi KTSP SMA di Yogyakarta. Laporan hasil penelitian unggulan UNY Tahun Anggaran 2010.

Thiagarajan, Sivasailam., Dorothy S. Semmel., Malvyn I. Semmel. 1974. Instructional Development for Training Teachers of Exceptional Children. Indiana: Eric.

Vockley, Martha., Vockley Lang. 2008. 21st Century Sklills, Education and Competitiveness; $A$ Resource and Policy Guide. Partnership for 21st Century Skills. www.21stcenturyskills.org. 
Wibowo, W S. 2014. Implementasi Model Project Based Learning (PjBL) dalam Pembelajaran Sains untuk Membangun 4Cs Skill Peserta didik Sebagai Bekal dalam Menghadapi Tantangan Abad 21. Makalah disajikan dalam Seminar Nasional IPA scientifict learning dalam konten dan konteks kurikulum 2013. 